See discussions, stats, and author profiles for this publication at: https://www.researchgate.net/publication/237427020

Two New Species Of Graphocephala Van Duzee From Costa Rica (Cicadellidae: Cicadellinae)

Article in Zootaxa · August 2006

Dol: 10.5281/zenodo.173572

CITATIONS

6

2 authors:

Carolina Godoy

Universidad Estatal a Distancia

7 PUBLICATIONS 24 CITATIONS

SEE PROFILE
READS

116

William Villalobos

University of Costa Rica

53 PUBLICATIONS 223 CITATIONS

SEE PROFILE 


\title{
Two new species of Graphocephala Van Duzee from Costa Rica (Cicadellidae: Cicadellinae)
}

\author{
CAROLINA GODOY ${ }^{1} \&$ WILLIAM VILLALOBOS ${ }^{2}$ \\ ${ }^{1}$ Museo de Zoología, Escuela de Biología, Universidad de Costa Rica, San Pedro de Montes de Oca. San José, \\ Costa Rica.E-mail: hansongodoy@ racsa.co.cr \\ ${ }^{2}$ Centro de Investigación en Biología Celular y Molecular, Universidad de Costa Rica, 2060, San José, Costa \\ Rica.E-mail: williamv@cariari.ucr.ac.cr
}

\begin{abstract}
The genus Grahocephala, which was described by Van Duzee (1916), is a large complex group distributed from southern Canada to Colombia, Venezuela, and French Guiana. Young (1977) revised the genus and described twelve new species. Later, Nielson and Godoy (1995) added five more species. In this paper two new species are described from Costa Rica: G. crusa and G. riverae. The first species showed positive DAS-ELISA results for the bacterium, Xylella fastidiosa.
\end{abstract}

Key words: Hemiptera, Auchenorryncha, leafhopper, taxonomy, Xylella, coffee

\section{Introduction}

The genus Graphocephala was described by Van Duzee (1916). It is a large complex group with more than 50 species and occurs from southern Canada to Colombia, Venezuela, and French Guiana. The country with the greatest number of species is Mexico, with 39, 19 of which are endemic. Young (1977) revised the genus and described twelve new species: alagarta, apicata, delongi, depicta, fennahi, kukla, penignava, psephena, pulchra, sasaima, simulata, and soluna. Nielson and Godoy (1995) later added five more species from Costa Rica. Presently, fifteen species are known from Costa Rica: albomaculata (Distant), aurolineata (Fowler), bivittata (Nielson \& Godoy), clepsydra (Fowler) coccinea (Föster), coronella (Nielson \& Godoy), distanti (Metcalf), edwardsi (Signoret), janzeni (Nielson \& Godoy), marathonensis (Olsen), nigricephala (Nielson \& Godoy), permagna (Nielson \& Godoy), redacta (Fowler), rufimargo (Walker), and versuta (Say). In this paper two new species are described from Costa Rica, G. crusa, and $G$. riverae. Adults of the first species were collected from Coffea arabica (Rubiaceae), 
growing with Persea americana (Lauraceae) and Citrus (Rutaceae). Preliminary analysis with the double antibody sandwich enzyme-linked immunosorbent assay (DAS-ELISA) detected the bacteria, Xylella fastidiosa, in the body of the leafhopper, although further tests are needed to determine whether it is a vector of the bacteria. This species is therefore of potential economic importance.

During the course of this study we also identified $G$ soluna, which we here record for the first time from Costa Rica.

\section{Material and methods}

The specimens from Costa Rica were collected with a suction pump and yellow sticky traps in Desamparados (San José), Carrizal (Alajuela), and Grecia (Alajuela). Oman's (1949) method of preparing leafhopper genitalia was followed, except that the abdomen was placed separately in $10 \%$ potassium hydroxide overnight at room temperature instead of being heated. The following day the genitalia were washed for five minutes in water.

Depositories: CAS_California Academy of Sciences, San Francisco, USA. INBio--Instituto Nacional de Biodiversidad, Santo Domingo, Heredia, Costa Rica. BNHM-The Natural History Museum, London, UK. UCR-University of Costa Rica, San Pedro, San José, Costa Rica.

Tests for the presence of Xylella fastidiosa in the body of the insect were carried out with a double antibody sandwich enzyme-linked immunosorbent assay (DAS-ELISA). The specimens were macerated in $200 \mu \mathrm{l}$ of general extracción buffer, following the protocol of Converse and Martin (1990).

\section{Genus Graphocephala Van Duzee}

Type Species. Cicada coccinea Forster, by original designation. Graphocephala Van Duzee 1916a:66.

Diagnosis. Male 4.2-9.4 mm. Color variable, most species with lenticular impressions on crown. Head weakly to well produced, anterior margin subangulate to broadly rounded in dorsal view; clypeus convex medially or nearly flattened, muscle impressions distinct or not. Thorax with pronotal width varying interspecifically compared with transocular width of head. Forewing with membrane distinct or not; veins distinct or not; in general with three closed anteapical cells and four apical cells; forewings of female in resting position exceeding apex of ovipositor. Hind leg almost always with femoral setal formula 2:1:1, length of first tarsomere variable in compararison to combined length of other two tarsomeres and with two rows of small setae on plantar surface. Male genitalia: Pygofer slightly to moderately produced, apex convex, with macroseae confined to apical half of disc, process on dorsal margin present or absent. Subgenital plate triangular, varying in 
length, with macro- or microsetae, arranged in one or several rows. Style extending posteriorly to a varying degree compared to extent of connective, without a distinct preapical lobe. Aedeagus with shaft usually short, almost always without processes, dorsal apodeme varying from large to very small. Paraphyses asymmetrical. Female abdominal sternum VII with margin produced posteriorly, its apex varying from rounded to obtusely or acutely angular.

\section{Graphocephala crusa Godoy, sp. nov. (Figs 1-5)}

Type material: Holotype, male, COSTA RICA: San José: Desamparado, 1200 m, 5-I2001, Col. C. Rodríguez (INBio). Paratypes 17 males and 9 females same data (CAS, NHM, UCR, INBio), 1 male same data except 8-II-2000 (UCR), 1 male and 2 females same data except 21-XII-2000 (INBio, UCR), 1 male and 2 females same data except XII2000 (UCR), 1 male same data except 29-X-2001 (UCR).

Description. Length of male 5.5-6.6 mm, female 5 5.-6.5 mm. General color green. Head produced, anterior margin subangulate, yellowish-green, with an apical spot, a small spot on each antennal ledge, an oblique linear mark on ocellocular area near inner eye margin, a broader linear mark on upper margin of area of muscle impression, and vertex with four black longitudinal lines, these connected apically and basally (Fig. 1); face uniform yellow, clypeus convex medially, muscle impressions distinct. Thorax with pronotal width shorter than transocular width of head; pronotum with broad yellow band bordering anterior margin, large green area occupying most of remainder. Scutellum yellow with black markings (Fig. 1). Forewing with membrane distinct; with three closed anteapical cells and four apical cells green, commissure yellow, claval suture dark brown to black. Spinulation of apex of hind knees 2:1:1; legs yellow, anterior tibia with distal spot dark brown and third tarsomere on fore leg dark brown; hind leg with length of first tarsomere approximately equal to combined length of two remaining tarsomeres.

Male genitalia: Pygofer in lateral view with concave caudodorsal margin, moderately produced, apex convex, with macrosetae confined to apical half of disc, process absent (Fig. 2). Subgenital plate triangular, not extending nearly as far posteriorly as pygofer apex, with uniseriate macrosetae (Fig. 2). Style without preapical lobe (Fig. 3). Connective with very long stem, extending beyond apex of styles (Fig. 3). Aedeagus in lateral view nearly V shaped, with shaft short, without processses, dorsal apodeme conspicuous (Figs. 4). Paraphyses consisting of a basis and two dissimilar rami of which the posterior one is broader and longer than the anterior one (Fig. 4).

Female abdominal sternum VII with margin produced posteriorly, the apex rounded (Fig. 5).

Distribution. Known only from Costa Rica. 


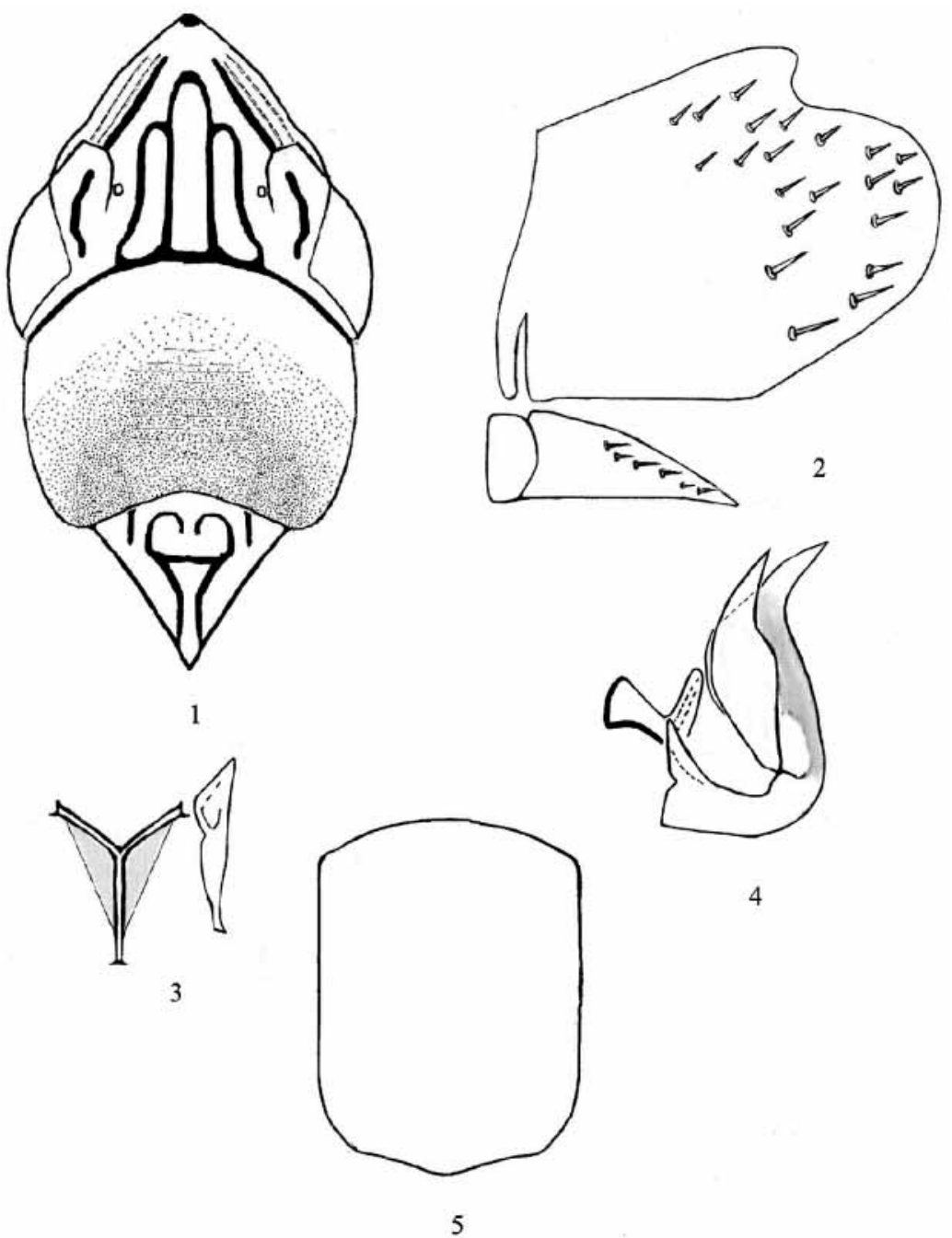

FIGURES 1-5. Graphocephala crusa, Godoy sp nov. (holotype). 1. Anterior dorsum, dorsal view; 2. Pygofer, subgenital plate and valve, lateral view; 3 . One style and connective, dorsal view; 4. Aedeagus, lateral view; 5. Female abdominal sternum VII, ventral view.

Diagnosis. This species is most similar to G. kukla (Young) in general habitus but $G$. crusa can be distinguished by the wider paraphyses and the configuration of the rami.

Natural History. The specimens were collected with a suction pump and yellow sticky traps in coffee, Coffea arabica (Rubiaceae), plantations. Tests utilizing DAS-E LISA detected the presence of Xylella fastidiosa in the bodies of this species, although tests have not yet been carried out to determine whether it is a vector of this bacteria.

Etymology. Named for the CRUSA fundation, which provided financial support for this project.

Biology. Of a total of 27 individuals which were tested with DAS-ELISA, 18 were positive for Xylella fastidiosa. 
Type material: Holotype, male, COSTA RICA: Heredia: P. N. Braulio Carrillo, Est. Barva, 2500 m, XII-1989, Col. A. Fernández, L-N 233400-523200 (INBio). Paratypes, 1 male same data as holotype except IX-1989 (INBio), 1 male same data except III-1990 (UCR), 2 males and 2 females same data (CAS, NHM, UCR, INBio), 2 males same data except V-1990 (INBio), 1 male and 1 female same data except VI-1990 (INBio), 1 female same data except XI-1989 B. Apu \& G. Varela (INBio), 2 females same data except VI1990 (INBio), female same data except VII-1990 (INBio).

Description. Length of male 7.0-8.2 $\mathrm{mm}$, female 7.7-8.3 $\mathrm{mm}$. General color yellowish green. Head moderately produced, anterior margin subangulate, broadly rounded in dorsal view; crown dark yellow with black markings, broad ivory-blue band along anterior margin, band bordered by thin black line; ocelli located on a line between anterior eye angles (Fig. 6); clypeus black, medially nearly flattened, muscle impressions distinct. Pronotum mostly dark green with light blue band anteriorly, band bordered with dark yellow or sometimes with black markings; pronotal width slightly greater than transocular width of head (Fig. 6). Scutellum yellowish green with black markings (Fig. 6). Forewing yellowish green with membrane not distinct, costal margin black, claval area darker; veins distinct; in general with three closed anteapical cells and four apical cells; forewings of female in resting position exceeding apex of ovipositor. Legs orange; hind leg with femoral setal formula 2:1:1, length of first tarsomere greater than combined length of two remaining tarsomeres and with two rows of small setae on plantar surface.

Male genitalia: Pygofer moderately produced, apex convex, with macroseae confined to apical half of disc, dorsal process absent (Fig. 7). Subgenital plate triangular with macrosetae arranged in one row (Fig. 7). Style extending posteriorly to a varying degree compared to extent of connective, without a distinct preapical lobe (Fig. 8). Connective with very long stem, extending beyond apex of styles (Fig. 8). Aedeagus in lateral view nearly V-shaped, with shaft short, without processes, dorsal apodeme conspicuous (Fig. 9). Paraphyses consisting of a basis and two rami, dorsal ramus shorter (Fig. 9). Female abdominal sternum VII with margin produced posteriorly, the apex varying from rounded to obtusely or acutely angular (Fig. 10).

Diagnosis. This species is similar to G. coronella in that the aedeagus is V-shaped in lateral view in both species, but the paraphyses are wider in G. riverae. In addition, the dorsal ramus is longer than that of G. coronella and the caudodorsal margin of the pygofer more deeply concave in lateral view.

Distribution. Known only from Costa Rica.

Biology. Unknown

Etymology. This species is name in honour of Carmen Rivera, in recognition of her dedication to the study of plant virology in Costa Rica. 


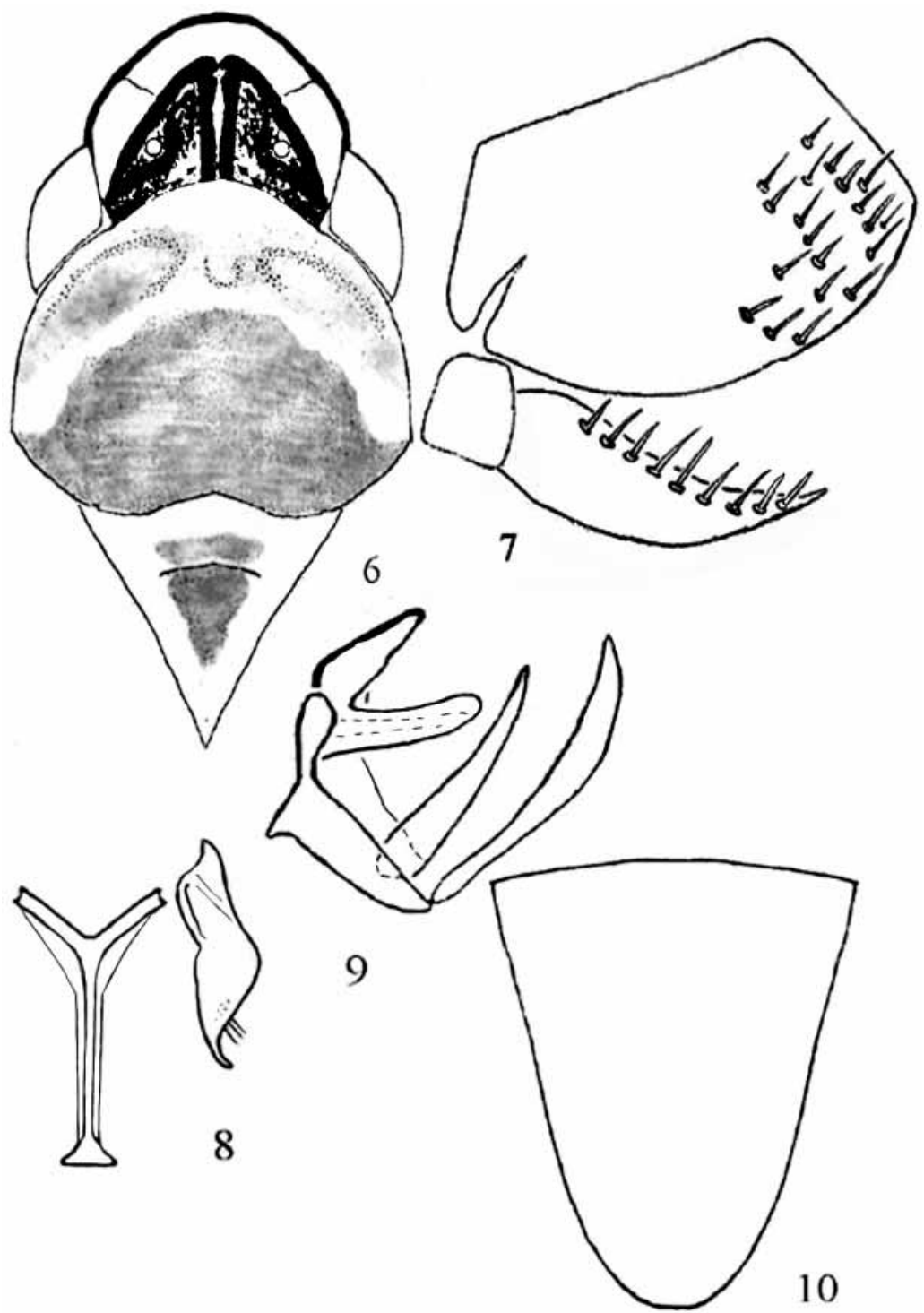

FIGURES 6-10. Graphocephala riverae, Godoy sp nov. (holotype). 6. Anterior dorsum, dorsal view; 7. Pygofer, subgenital plate and valve, lateral view; 8 . One style and connective, dorsal view; 9. Aedeagus, lateral view; 10. Female abdominal sternum VII, ventral view.

\section{Key to male Graphocephala of Costa Rica (modified from Nielson \& Godoy, 1995)}

1 Pygofer with a distinct process on dorsal margin................................................... 2

- Pygofer without process, dorsal margin rounded ...................................................... 3

2 Pygofer process large, very prominent (figure in Young 1977).....aurolineata (Fowler)

- Pygofer process small (figure in Young 1977). edwardsi (Signoret) 
3 Pygofer apex quadrate (Fig. 7) ......................................................... riverae $\mathbf{s p .}$ nov.

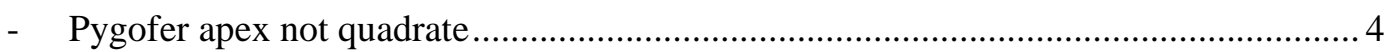

4 Pygofer in lateral view with caudodorsal margin concave; paraphyses with two broad and dissimilar rami, the posterior one broader and longer than the anterior one (Figs. 2, 4) crusa sp. nov.

- Pygofer with caudodorsal margin not concave, or if concave, then rami of paraphyses not as broad 5

5 Head with lenticular impressions on crown (figure in Young 1977) .. redacta (Fowler)

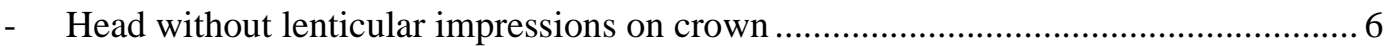

6 Crown short, median length less than $1 / 2$ interocular width ......................................... 7

- Crown long, median length more than $1 / 2$ interocular width....................................... 8

7 Dorsum black with spots and markings on forewings, never striped (figure in Young 1977) albomaculata (Distant)

- Dorsum yellowish to grey-green, black spots on crown and pronotum; dark stripes on forewings (figure in Young 1977). marathonensis (Olsen)

8 Anterior dorsum yellow, one dark spot each on crown and pronotum and scutellum, 2 dark spots on pronotum; large robust species (figure in Young 1977) distanti Metcalf

- Anterior dorsum not as above; short to long slender species.

9 Crown entirely black; pronotum black with broad yellow-green to orange band in middle nigricephala Nielson \& Godoy

- Crown and pronotum not so marked 10

10 Crown with conspicuous marginal black stripe separated by pale crown from pale face (figure in Young 1977) .coccinea (Föster)

- Crown not so marked 11

11 Rami of paraphyses constricted medially (figure in Young 1977). versuta (Say)

- Rami of paraphyses not constricted medially 12

12 Crown with distinct apical spot, disk yellowish with 2 narrowly diverging band, longitudinal fuscous stripe below (figure in Young 1977). clepsydra (Fowler)

- Crown not so marked 13

13 Crown with broad ivory to yellow band on anterior margin from apex to inner margin of eyes, band bordered by thin to broad black line

- Crown not so marked

14 Crown with thin black line bordering ivory anterior band, disk tannish with black markings coronella Nielson \& Godoy

- Crown with broad black line bordering yellow anterior band, disk tannish with black markings permagna Nielson \& Godoy

15 Crown and pronotum with two pair of red to black longitudinal stripes bivittata Nielson \& Godoy

- Crown and pronotum not so marked 16

16 Small species, length less than $5.8 \mathrm{~mm}$; crown with several thin black lines and mark- 
- $\quad$ Larger species, length more than $6.3 \mathrm{~mm}$.; crown with broad black markings janzeni Nielson \& Godoy

\section{Acknowledgements}

The authors thank the CR-USA foundation for financial support and Paul Hanson (University of Costa Rica) for comments on the manuscript.

\section{References}

Converse, R.H, \& Martin, R.R. (1990). ELISA methods for plant viruses. In: Hampton, R., Ball, E., $\&$ DeBoer, S. (Eds.), Serological Methods for Detection and Identification of Viral and Bacterial Plant Pathogens. APS Press, St. Paul, pp. 179-196.

Nielson, M.W. \& Godoy, C. (1995). Studies on the Leafhoppers of Central America (Homoptera: Cicadellidae). Contributions Entomology, International. 2, 210-217.

Oman, P.W. (1949). The Neartic Leafhoppers (Homoptera:Cicadellidae). A Generic Classification and Check List. Memoirs of the Entomological Society of Washington, 3, 1-253.

Young, D.A (1977). Taxonomic study of the Cicadellinae (Homoptera: Cicadellidae). Part 2. New World Cicadellini and the Genus Cicadella. Technical Bulletin, 239, 1-1135. 